\title{
Plant and Bacterial Chitinases Differ in Antifungal Activity
}

\author{
By WALDEN K. ROBERTS ${ }^{1 *}$ AND CLAUDE P. SELITRENNIKOFF ${ }^{2}$ \\ ${ }^{1}$ Department of Microbiology and Immunology, and \\ ${ }^{2}$ Department of Cellular and Structural Biology, University of Colorado Health Sciences Center, \\ Denver, Colorado 80262, USA
}

(Received 13 May 1987; revised 14 August 1987)

\begin{abstract}
Chitinases were isolated from the grains of wheat, barley and maize, and compared with those obtained from Serratia marcescens, Streptomyces griseus and Pseudomonas stutzeri for antifungal activity and enzyme specificity. The six enzymes were tested for antifungal activity using an assay based upon inhibition of hyphal extension of the fungi Trichoderma reesei and Phycomyces blakesleeanus. Antifungal activity was observed with as little as $1 \mu \mathrm{g}$ of each of the grain chitinases, whereas none of the bacterial chitinases had any effect on hyphal extension, even at $50 \mu \mathrm{g}$ chitinase per assay. This difference in antifungal activity correlated with the different mechanisms of action of the two classes of enzymes. In common with other plant chitinases, the grain chitinases functioned as endochitinases and contained lysozyme activity. In contrast, the bacterial enzymes were exochitinases and hydrolysed the chromogenic trisaccharide analogue $p$-nitrophenyl- $\beta$-D- $N, N^{\prime}$-diacetylchitobiose, which proved to be an excellent substrate for assaying bacterial chitinases. These experiments strengthen the hypothesis that plant chitinases function to protect the host against fungal infections.
\end{abstract}

\section{INTRODUCTION}

Chitin, an insoluble linear $\beta$-1,4-linked polymer of $N$-acetylglucosamine, is a common constituent of fungal cell walls and of the exoskeletons of arthropods. All organisms that contain chitin also contain chitinases (poly- $\beta$-1,4-(2-acetamido-2-deoxy)-D-glucoside glycanohydrolases, EC 3.2.1.14), which are presumably required for morphogenesis of cell walls and exoskeletons (Gooday, 1977). Other organisms that do not contain chitin may produce chitinases to degrade the polymer for food, e.g. soil bacteria that secrete chitinases in response to chitin in their environment (Oranusi \& Trinci, 1985) and the digestive tract of fish (Danulat \& Kausch, 1984). Plants also have been found to contain chitinase, often after enzyme synthesis has been induced by microbial infections or other injuries (Pegg \& Young, 1982; Boller et al., 1983; Boller, 1985). Since plants do not contain chitin in their cell walls, it has been postulated that they produce chitinase to protect themselves from chitin-containing parasites (fungi, insects) (Abeles et al., 1970 ; Bell, 1981; Boller, 1985), but direct evidence supporting this hypothesis has been lacking (Boller, 1985).

Recently we reported the isolation of two antifungal proteins from barley grain (Roberts \& Selitrennikoff, 1986a). The more active of these, a $28 \mathrm{kDa}$ protein, was shown to be a chitinase (Roberts \& Selitrennikoff, $1986 b$ ). To our knowledge, this was the first report of inhibition of fungal growth by a chitinase acting alone, and we were interested to know whether antifungal activity was unique to the barley enzyme or was a general property of plant chitinases. Also, we wanted to investigate antifungal activity of bacterial chitinases, since these enzymes differ from plant chitinases in their mechanism of action (Molano et al., 1977, 1979; Roberts \& Cabib, 1982; Boller et al., 1983) and this might affect their antifungal activity.

In this report we show that plant and bacterial chitinases differ markedly in antifungal activity, and that this difference in biological activity correlates with differences in their substrate specificities. 


\section{METHODS}

Chitinase preparations. Chitinases from Serratia marcescens and Pseudomonas stutzeri were generous gifts from Dr Roy Fuchs, Monsanto Company, St Louis, Missouri, USA. The Sa. marcescens chitinase was prepared by cloning the gene into Escherichia coli, where it was expressed and the protein purified to yield a single $57 \mathrm{kDa}$ band upon analysis by SDS-PAGE (Fuchs et al., 1986). The $60 \mathrm{kDa} P$. stutzeri chitinase was similarly prepared. Chitinase from Streptomyces griseus was purchased from Sigma and purified by chitin adsorption and elution (Molano et al., 1977). Grain chitinases were isolated using the procedure previously described for purification of the $28 \mathrm{kDa}$ antifungal chitinase from barley (Roberts \& Selitrennikoff, 1986a). Analysis by SDS-PAGE showed that both the wheat and barley preparations contained single $28 \mathrm{kDa}$ proteins, whereas the maize preparation contained two broad protein bands with apparent molecular masses of $26 \mathrm{kDa}$ and $22 \mathrm{kDa}$. These two proteins could be resolved by gradient elution from a CM-Sephadex column and both showed chitinase activity (not shown).

Assay for antifungal activity. Antifungal activity was estimated using the hyphal extension-inhibition assay described earlier (Roberts \& Selitrennikoff, 1986a). A suspension of fungal conidia was placed on a central disc on an agar plate and protein solutions to be tested were added to perimeter discs. Resulting hyphae grew outward from the central disc as a circle, unless an effective concentration of inhibitor was contacted in a perimeter disc. In the latter case, a crescent of growth inhibition was observed around the disc.

Agar plate assay for chitinase and lysozyme. A $20 \mathrm{~g}$ sample of crab-shell chitin (Sigma) was dissolved in cold concentrated $\mathrm{HCl}(350 \mathrm{ml})$ and placed at $4^{\circ} \mathrm{C}$ for $24 \mathrm{~h}$. The mixture was filtered through glass wool into $2 \mathrm{l}$ ethanol at $-20^{\circ} \mathrm{C}$ with rapid stirring. The resulting chitin suspension was centrifuged at $10000 \mathrm{~g}$ for $20 \mathrm{~min}$; chitin pellets were washed repeatedly with water until the $\mathrm{pH}$ was neutral, and the washed chitin was lyophilized to dryness and stored at $-20^{\circ} \mathrm{C}$. To prepare chitin plates, chitin was resuspended in water $\left(1 \mathrm{mg} \mathrm{ml}^{-1}\right)$ by passing suspensions five times through a hand-operated cream homogenizer (VWR Scientific). The chitin suspension was diluted with an equal volume of $1.6 \%(\mathrm{w} / \mathrm{v})$ Bacto Nutrient Broth (Difco), agar was added to $2 \%(\mathrm{w} / \mathrm{v})$, the suspensions were autoclaved, and $10 \mathrm{ml}$ volumes of agar were poured into $100 \mathrm{~mm}$ Petri plates. After the agar had solidified, $6 \mathrm{~mm}$ ( 0.25 inch) diameter blank paper discs (BBL) were placed on the agar, $30 \mu$ of the chitinase samples to be tested were added to each disc, and the plates were incubated at $35^{\circ} \mathrm{C}$ for $48 \mathrm{~h}$. Chitin hydrolysis was indicated by zones of clearing around the discs.

Lysozyme assays were done in a similar manner. Lyophilized Micrococcus lysodeikticus cells (Sigma) were

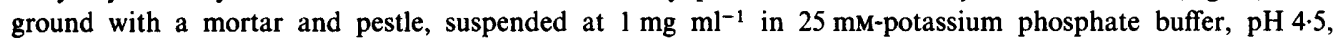
containing $50 \mathrm{~mm}-\mathrm{NaCl}$ and $0.02 \%(\mathrm{w} / \mathrm{v}) \mathrm{NaN}_{3}$, and the mixture passed five times through the cream homogenizer to produce a fine suspension of bacteria. The suspension was used to prepare $2 \%(\mathrm{w} / \mathrm{v})$ agar plates, and chitinase samples were added to paper discs on the agar and the plates incubated as described above. Clearing around the discs indicated cell wall hydrolysis (lysozyme activity).

Hydrolysis of radioactive chitin. Radioactive chitin, with a specific activity of 122 c.p.m. per nmol of $N$ acetylglucosamine equivalents, was prepared by acetylating chitosan with tritiated acetic anhydride (Molano et al., 1977). This chitin was added to $0.05 \mathrm{M}$-potassium phosphate buffer $(\mathrm{pH} 6.0)$ containing $0.02 \%(\mathrm{w} / \mathrm{v}) \mathrm{NaN}_{3}$, and a fine suspension $\left(1 \mathrm{mg} \mathrm{ml} \mathbf{~}^{-1} ; 6 \times 10^{5} \mathrm{c}\right.$.p.m. $\left.\mathrm{ml}^{-1}\right)$ was obtained using a Duall homogenizer. Chitinase assays were done essentially as described by Molano et al. (1977), except that chitin suspensions were incubated with $15 \mu \mathrm{g}$ chitinase $\mathrm{ml}^{-1}$ at $50{ }^{\circ} \mathrm{C}$. At timed intervals, $0.2 \mathrm{ml}$ portions were removed, added to $0.2 \mathrm{ml}$ ice-cold $10 \%$ $(\mathrm{w} / \mathrm{v}) \mathrm{TCA}$, the precipitates removed by centrifugation, and the soluble radioactivity determined by liquid scintillation counting. For reaction-product identification, suspensions of radioactive chitin were incubated as above and the reactions stopped after $60 \mathrm{~min}$ by the addition of glacial acetic acid to $1 \%(\mathrm{v} / \mathrm{v})$. Reaction mixtures were stored overnight at $4{ }^{\circ} \mathrm{C}$, precipitates removed by centrifugation, and oligosaccharides in $25 \mu \mathrm{l}$ ( $\mathrm{Sa}$. marcescens chitinase digest) or $50 \mu \mathrm{l}$ (wheat-germ chitinase digest) of each supernatant fraction separated by TLC on Silica Gel 60 TLC plastic sheets (Merck) (Boller et al., 1983). Bands (5 mm pieces) were cut from each track, the radioactivity of each was counted, and the migration positions were compared to those of $N$-acetylated derivatives of glucosamine, chitobiose, chitotriose and chitotetraose, which were chromotographed in parallel tracks and detected by a sulphuric acid charring method (Hertelendy \& Common, 1964).

Chromogenic assay procedure. The chromogenic substrate, $p$-nitrophenyl- $\beta$ - $\mathrm{D}-N, N^{\prime}$-diacetylchitobiose (Sigma), was dissolved at $300 \mu \mathrm{g} \mathrm{ml}^{-1}$ in $0.05 \mathrm{M}$-potassium phosphate buffer $\left(\mathrm{pH} \mathrm{6.0)}\right.$ containing $0.02 \%(\mathrm{w} / \mathrm{v}) \mathrm{NaN}_{3}$, and $100 \mu \mathrm{l}$ portions were distributed into wells of a 96 flat bottom well Micro Test II tissue culture plate (Falcon Products). The plate was placed on ice, chitinase samples $(10 \mu \mathrm{l})$ were added to each well, and incubations were initiated by floating the plate in a $50^{\circ} \mathrm{C}$ water bath. Reactions were terminated by the addition of $5 \mu \mathrm{l} 1 \mathrm{M}-\mathrm{NaOH}$ to each well, which also served to develop the colour of the $p$-nitrophenol formed by chitinase cleavage of the substrate. Absorbance at $410 \mathrm{~nm}$ was measured using an MR 600 microplate reader (Dynatech Instruments). 

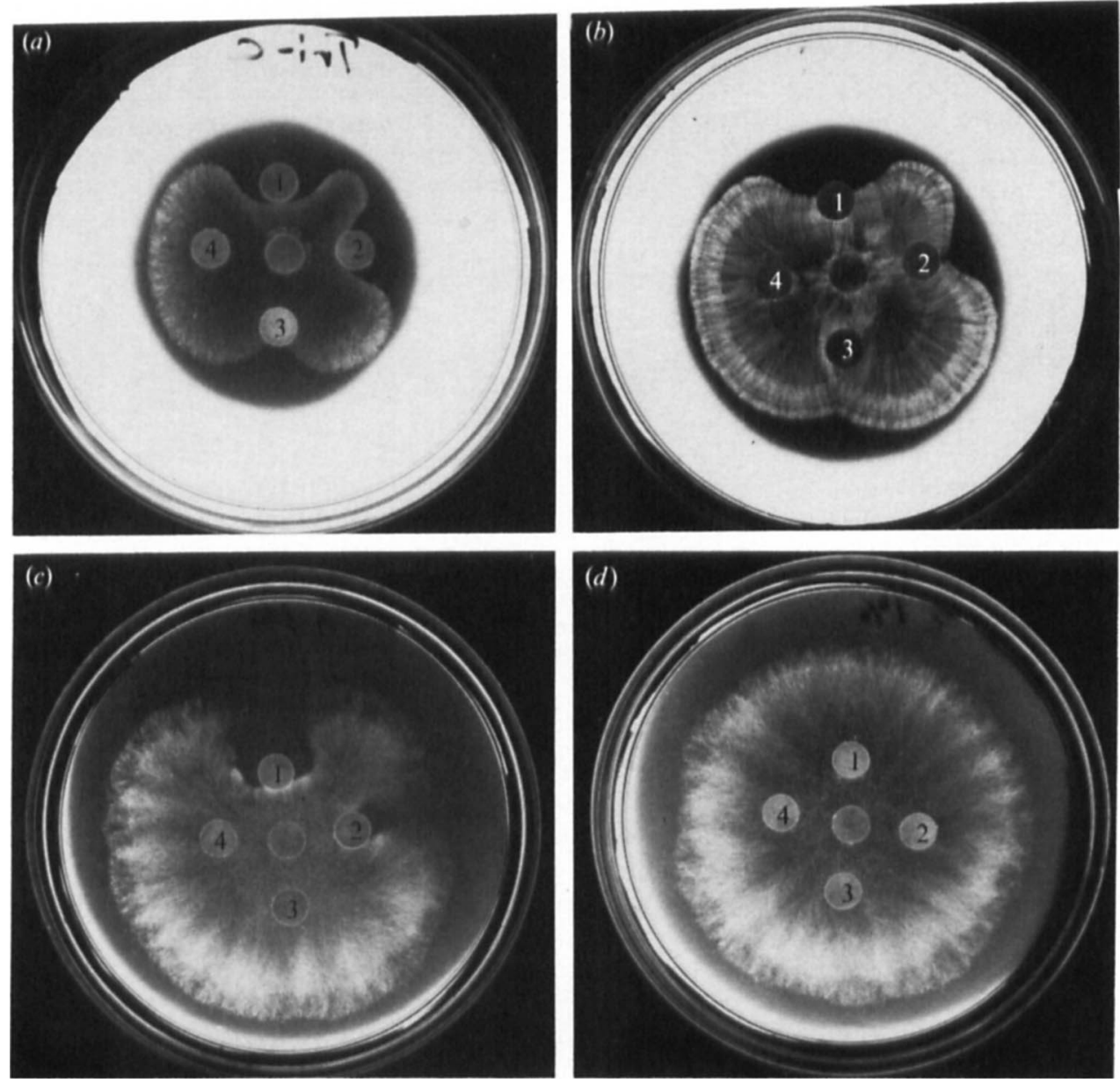

Fig. 1. Inhibition of fungal growth by chitinases. Blank paper discs were placed on carrot-juice agar plates and conidia from Trichoderma reesei $(a, c$ and $d)$ or Phycomyces blakesleeanus $(b)$ were inoculated onto the central disc. In (a), the discs contained $10,3,1$ and $0.3 \mu \mathrm{g}$ (discs $1-4$, respectively) of corn chitinase; in (b), the discs contained 30,10,3 and $1 \mu \mathrm{g}$ (discs 1-4, respectively) of corn chitinase; in (c), the discs contained $30,3,0.3$ and $0 \mu \mathrm{g}$ (discs $1-4$, respectively) of barley chitinase; in $(d)$, the discs contained $50 \mu \mathrm{g}$ of the chitinases from Sm. griseus (disc 1), Sa. marcescens (disc 2), P. stutzeri (disc 3), or buffer alone (disc 4).

\section{RESULTS}

\section{Antifungal activity}

The purified chitinases from barley, maize, wheat and $S m$. griseus, and the cloned chitinase gene products from $S a$. marcescens and $P$. stutzeri, were tested for antifungal activity by their ability to inhibit hyphal extension (Roberts \& Selitrennikoff, 1986a). Growth of Trichoderma reesei was inhibited by 10,3 and $1 \mu \mathrm{g}$ (discs $1-3$, respectively), but not by $0 \cdot 3 \mu \mathrm{g}$ (disc 4 ), of the chitinase isolated from maize (Fig. 1 a). In a similiar assay using Phycomyces blakesleeanus as the indicator organism, as little as $3 \mu \mathrm{g}$ of maize chitinase gave detectable growth inhibition (Fig. $1 b$ ). All three grain chitinases inhibited growth of both $T$. reesei and $P$. blakesleeanus (Table 1 , lines 1 and 2), indicating that the antifungal effect is not restricted to a single chitinase nor to a single fungal species. 
Table 1. Comparison of antifungal and enzymic activities between grain and bacterial chitinases

\begin{tabular}{|c|c|c|c|c|c|c|}
\hline \multirow[b]{2}{*}{ Activity assayed } & \multicolumn{6}{|c|}{ Source of chitinase } \\
\hline & Barley & Maize & Wheat & P. stutzeri & Sa. marcescens & Sm. griseus \\
\hline $\begin{array}{l}\text { Growth inhibition of } \\
P . \text { blakesleeanus* } \\
\text { Growth inhibition of }\end{array}$ & 3 & 3 & 10 & $>50$ & $>50$ & $>50$ \\
\hline T. reesei ${ }^{*}$ & 1 & 1 & $0 \cdot 3$ & $>50$ & $>50$ & $>50$ \\
\hline Hydrolysis of chitin in agart & 10 & 10 & 10 & $0 \cdot 1$ & 1 & 1 \\
\hline $\begin{array}{l}\text { Hydrolysis of bacterial cell } \\
\text { walls in agart } \\
\text { Hydrolysis of radioactive }\end{array}$ & 10 & 10 & $0 \cdot 3$ & $>50$ & $>50$ & $>50$ \\
\hline $\begin{array}{l}\text { chitin } \ddagger \\
\text { Hydrolysis of } p \text {-nitrophenyl- }\end{array}$ & ND & ND & $4 \cdot 2$ & $5 \cdot 1$ & 6.5 & ND \\
\hline$\beta$-D- $N, N^{\prime}$-diacetylchitobiose $\S$ & $<0 \cdot 1$ & $<0 \cdot 1$ & $<0 \cdot 1$ & 60 & 32 & 20 \\
\hline
\end{tabular}

ND, Not determined.

* Values given are minimum amounts of chitinase ( $\mu \mathrm{g}$ protein per disc) required to produce detectable fungal growth inhibition.

$\dagger$ Values given are minimum amounts of chitinase ( $\mu \mathrm{g}$ protein per disc) required to produce detectable polymer hydrolysis.

$\ddagger$ Activities are expressed as $\mu \mathrm{mol} N$-acetylglucosamine solubilized $\min ^{-1}$ (mg protein $)^{-1}$.

$\S$ Activities are expressed as $\mu \mathrm{mol} p$-nitrophenol released $\min ^{-1}$ (mg protein) ${ }^{-1}$.

Growth inhibition assays using $T$. reesei are shown for barley chitinase and the bacterial chitinases in Fig. $1(c, d)$. Barley chitinase was tested at 30, 3,0.3 and $0 \mu \mathrm{g}$ per disc (Fig. $1 c$, discs 1-4 respectively), and growth inhibition was seen at $3 \mu \mathrm{g}$ but not $0.3 \mu \mathrm{g}$ chitinase. The bacterial chitinases were all tested at $50 \mu \mathrm{g}$ per disc (Fig. 1d); no growth inhibition was observed with any of the bacterial chitinases, even at this high concentration. Similarily, the bacterial chitinases did not inhibit growth of $P$. blakesleeanus (Table 1, line 1).

\section{Hydrolysis of chitin}

The difference in antifungal activities between the grain and bacterial chitinases could be explained if the two classes of enzymes differed markedly in their specific activities. To investigate this possibility, the six chitinases were compared with respect to their ability to hydrolyse two chitin substrates.

The first assay utilized purified crab-shell chitin suspended in agar, with chitinase samples added to paper discs on the agar and the agar plates incubated to permit chitin hydrolysis. All six enzymes hydrolysed chitin in this assay; results from four of these are shown in Fig. 2(a). Clear zones resulting from chitin degradation are visible around discs containing $30 \mu \mathrm{g}$ of the chitinases from Sm. griseus (disc 1), Sa. marcescens (disc 2), barley (disc 3) and maize (disc 4). The second assay measured the release of acid-soluble radioactivity from radioactively labelled chitin (Molano et al., 1977). The specific activities of the bacterial chitinases were as high as or higher than the grain chitinases in both chitin-hydrolysing assays (Table 1, lines 3 and 5). For example, endpoint dilution experiments using the agar plate assay showed detectable chitin hydrolysis with a minimum of $10 \mu \mathrm{g}$ of barley chitinase and $1 \mu \mathrm{g}$ of $\mathrm{Sm}$. griseus chitinase. Also, the specific activities of the chitinases from Sa. marcescens and wheat were 6.5 and $4.2 \mu \mathrm{mol}$ $N$-acetylglucosamine $\min ^{-1}(\mathrm{mg} \text { protein })^{-1}$, respectively, for the release of acid-soluble radioactivity from radioactive chitin. Thus, the inability of the bacterial chitinases to inhibit fungal growth cannot be attributed to a reduced capacity to hydrolyse chitin (at least the purified, partially degraded chitins used as substrates in these assays).

\section{Hydrolysis of bacterial cell walls}

The peptidoglycan of bacterial cell walls is hydrolysed by lysozymes and contains alternating $\beta$-1,4-linked residues of $N$-acetylglucosamine and $N$-acetylmuramic acid in its polysaccharide backbone, resembling in structure the $\beta$-1,4-linked $N^{\prime}$-acetylglucosamine polymer of chitin. 

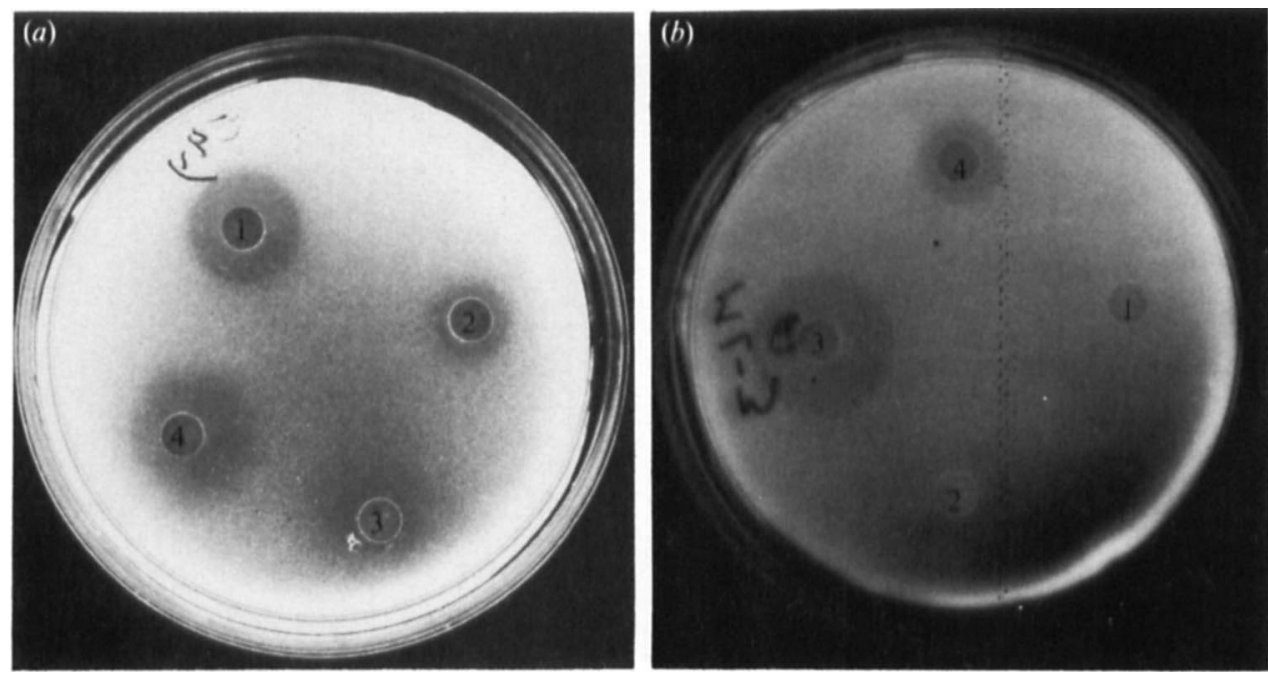

Fig. 2. Agar plate assay for chitinase degradation of chitin and bacterial cell walls. Blank paper discs were placed on plates containing chitin (a) or $M$. lysodeikticus cells $(b)$ suspended in agar. Chitinase samples were added to the discs and the plates were incubated and examined for zones of clearing around the discs. In $(a)$, the discs contained $30 \mu \mathrm{g}$ of the chitinases from Sm. griseus (disc 1), Sa. marcescens (disc 2), barley (disc 3) and maize (disc 4). In (b), the discs contained $30 \mu \mathrm{g}$ of the chitinases from Sm. griseus (disc 1), Sa. marcescens (disc 2), wheat (disc 3) and barley (disc 4).

Recently, careful examination of several plant proteins has shown that lysozyme and chitinase activity can represent two enzyme activities of the same protein (Boller, 1985). To extend this observation to include grain chitinases, and to determine whether lysozyme activity correlates with antifungal activity, the grain and bacterial chitinases were tested for their abilities to hydrolyse bacterial cell walls.

Lysozyme activity was assayed by suspending cell walls of $M$. lysodeikticus in agar, adding chitinase samples to paper discs on the agar plates, incubating the plates, and examining for zones of clearing around the discs (Fig. $2 b$ ). Chitinases from Sm. griseus (disc 1) or $S a$. marcescens (disc 2) did not cause cell wall degradation, but degradation was observed by the chitinases from wheat (disc 3 ) and barley (disc 4). A separate experiment showed hydrolysis by the corn chitinase but not by the P. stutzeri chitinase (Table 1 , line 4). Thus, only the grain chitinases can effectively utilize peptidoglycan as a substrate.

\section{Analysis of chitin degradation products}

Chitinases from Sm. griseus and Sa. marcescens have been shown to degrade chitin by an exohydrolytic mechanism (Molano et al., 1977; Roberts \& Cabib, 1982). These enzymes remove the disaccharide diacetylchitobiose from the nonreducing end of chitin in a stepwise fashion (Roberts \& Cabib, 1982), and significant amounts of monosaccharide or oligosaccharides do not appear in reaction mixtures. In contrast, chitinases from wheat-germ (Molano et al., 1979) and bean leaf (Boller et al., 1983) degrade chitin by an endohydrolytic mechanism, and the $\mathrm{N}$ acetylated derivatives of chitobiose, chitotriose and chitotetraose all accumulate in reaction mixtures.

These mechanisms of action were confirmed for our chitinase preparations (Fig. 3). Digestion of radioactively labelled chitin with the $S a$. marcescens $57 \mathrm{kDa}$ chitinase produced a single product comigrating with diacetylchitobiose, as expected for an exochitinase. In contrast, hydrolysis using the wheat enzyme gave products migrating as di-, tri- and tetrasaccharides, characteristic of digestion of chitin by an endochitinase. Hydrolysis of chitin using the $P$. stutzeri enzyme yielded diacetylchitobiose as the primary product (not shown), indicating that in common with the other bacterial chitinases this enzyme is an exochitinase. 


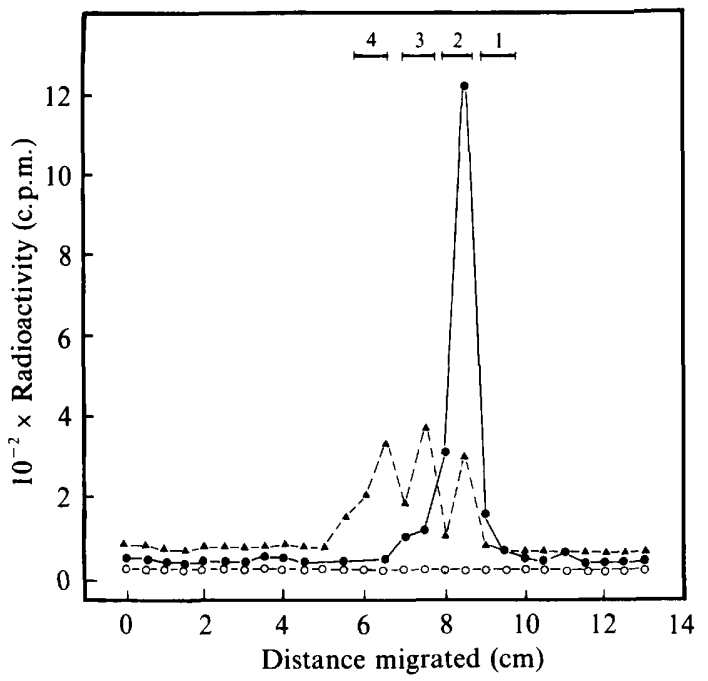

Fig. 3

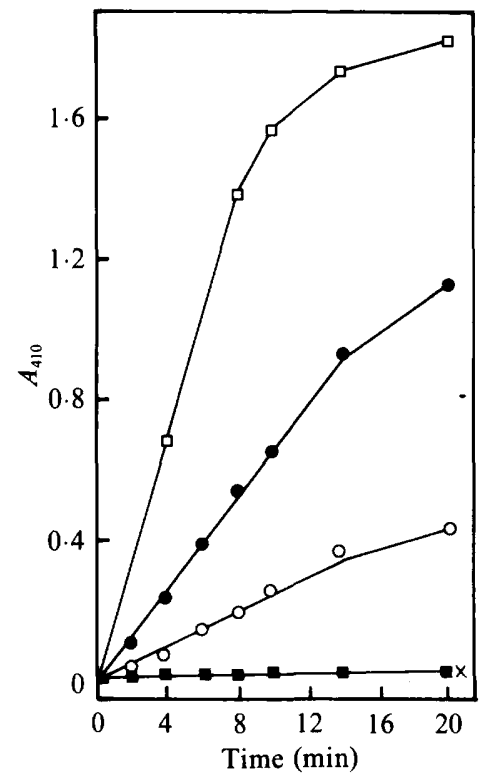

Fig. 4

Fig. 3. TLC of chitin degradation products. Radioactive chitin was incubated with Sa. marcescens chitinase $(\boldsymbol{O})$, wheat-germ chitinase $(\boldsymbol{\Lambda})$, or no enzyme $(O)$. The soluble reaction products were separated by TLC on silica gel sheets and detected by counting radioactivity in bands cut from the sheets. Markers 1-4 show the positions of $\mathrm{N}$-acetylated derivatives of glucosamine, chitobiose, chitotriose and chitotetraose, respectively.

Fig. 4. Hydrolysis of a chromogenic substrate by chitinases. The chromogenic trisaccharide analogue $p$ nitrophenyl- $\beta$-D- $N, N^{\prime}$-diacetylchitobiose was incubated with $S a$. marcescens chitinase at $1.5(O), 5(O)$ or $15(\square) \mu \mathrm{g} \mathrm{ml}^{-1}$, with $80 \mu \mathrm{g}$ wheat-germ chitinase $\mathrm{ml}^{-1}(\square)$, or with no enzyme added $(\times)$.

\section{A convenient chromogenic substrate for bacterial chitinases}

The compound $p$-nitrophenyl- $\beta$-D- $N, N^{\prime}$-diacetylchitobiose was originally synthesized as a potential chromogenic substrate for lysozyme (Osawa, 1966). However, its structure suggests that it might be a more appropriate substrate for chitinase although, to our knowledge, its use as a chitinase substrate has not been reported. This possibility was examined, since the compound is readily available commercially and a convenient chromogenic assay would greatly facilitate any study involving the purification and properties of chitinases.

The six chitinases were tested for their ability to hydrolyse $p$-nitrophenyl- $\beta$-D- $N, N^{\prime}$ diacetylchitobiose. The chitinase from Sa. marcescens released $p$-nitrophenol from the substrate at enzyme concentrations as low as $1.5 \mu \mathrm{g}$ protein $\mathrm{ml}^{-1}$, but the substrate was completely resistant to $80 \mu \mathrm{g}$ protein $\mathrm{ml}^{-1}$ of the wheat chitinase (Fig. 4). Other experiments demonstrated that the chromogenic substrate was rapidly hydrolysed by $1.5 \mu \mathrm{g}$ protein $\mathrm{ml}^{-1}$ of the chitinases from Sm. griseus and P. stutzeri, but was resistant to hydrolysis by $100 \mu \mathrm{g}$ protein $\mathrm{ml}^{-1}$ of the chitinases from barley and maize (Table 1 , line 6 ). Thus, $p$-nitrophenyl- $\beta$-D- $N, N^{\prime}$-diacetylchitobiose was an excellent chromogenic substrate for the bacterial chitinases but was resistant to hydrolysis by the grain chitinases. None of the enzymes hydrolysed the $p$-nitrophenyl- $\beta$-D derivatives of $\mathrm{N}$-acetylglucosamine or cellobiose (data not shown).

\section{DISCUSSION}

Hydrolysis of $p$-nitrophenyl- $\beta$-D- $N, N^{\prime}$-diacetylchitobiose by bacterial chitinases is probably a reflection of the exochitinase mechanism of action of these enzymes. The exochitinolytic splitting of diacetylchitobiose from the nonreducing end of this substrate liberates $p$-nitrophenol 
as the product. In contrast, plant endochitinases would not be expected to hydrolyse this chromogenic trisaccharide analogue, since triacetylchitotriose accumulates when chitin is digested with endochitinases (Molano et al., 1979; Boller et al., 1983; Fig. 3). These data suggest that $p$-nitrophenyl- $\beta$-D- $N, N^{\prime}$-diacetylchitobiose is a valuable reagent, both as a convenient substrate for assaying exochitinases and as an indicator of the mechanism of hydrolysis for chitinases. In this regard, it should be remembered that this compound is not specific for chitinases and, in principle, may also serve as substrate for lysozymes and exo- $\beta-N$ acetylglucosaminidases. However, the specific activity of the $S$. marcescens chitinase is over 200fold greater than the specific activities of jack-bean $\beta$ - $N$-acetylglucosaminidase or egg-white lysozyme for hydrolysis of the substrate (unpublished data). This suggests that hydrolysis of the chromogenic substrate by non-chitinases may not be a significant problem.

A possible explanation for the fact that antifungal activity is limited to the grain chitinases is that these enzymes function as endochitinases and can cleave any portion of a chitin polymer with which they come in contact. The bacterial chitinases, being exochitinases, are restricted to locating nonreducing termini of chitin as substrates, which may be difficult in intact fungal cell walls. Inaccessibility of termini may also play a role in the inability of exochitinases, but not endochitinases, to hydrolyse bacterial cell walls, although this difference in specificity could easily be due to other factors. Both exochitinases and endochitinase degrade chitin efficiently in standard chitinase assays, but these normally use purified, partially degraded chitin as substrate, and would contain numerous termini available for exochitinase attack. The inability of exochitinases to inhibit fungal growth suggests that any future experiments designed to introduce chitinase genes into plants to improve their resistance to fungal attack (Nitzsche, 1983) should use chitinase genes from other plants, rather than from bacteria.

After this work had been completed, a report appeared by Schlumbaum et al. (1986) describing the inhibition of fungal growth by the chitinase from bean leaves. In addition, these investigators found antifungal activity associated with commercial chitin-binding lectins from wheat-germ, tomato, potato, pokeweed and gorse, but only if the lectins were contaminated with the corresponding chitinases. These results, together with our own using grain chitinases, suggest that antifungal chitinases may be widely distributed throughout the plant kingdom, either in stems and leaves following induction by ethylene or pathogen attack (Boller, 1985), or stored in seeds as a means of increasing the seeds' resistance to fungi in the soil (Powning \& Irzykiewicz, 1965). Presumably, these chitinases, by acting directly on growing hyphal tips or in concert with other hydrolytic enzymes (Schlumbaum et al., 1986), help limit and define the fungal species that can successfully parasitize plants.

We are grateful to Dr Roy L. Fuchs, Monsanto Chemical Company, for his generous gift of cloned $57 \mathrm{kDa}$ Serratia marcescens chitinase and cloned $60 \mathrm{kDa}$ Pseudomonas stutzeri chitinase. This investigation was supported in part by NSF award DCB 8500233 (to C.P.S.).

\section{REFERENCES}

Abeles, F. B., Bosshart, R. P., Forrence, L. E. \& Habig, W. H. (1970). Preparation and purification of glucanase and chitinase from bean leaves. Plant Physiology 47, 129-134.

Bell, A. A. (1981). Biochemical mechanisms of disease resistance. Annual Reviews of Plant Physio$\log y$ 32, 21-81.

BOLLER, T. (1985). Induction of hydrolases as a defense reaction against pathogens. In Cellular and Molecular Biology of Plant Stress, pp. 247-262. Edited by J. L. Key \& T. Kosuge, New York: Alan R. Liss, Inc.

Boller, T., Gehri, A., Mauch, F. \& Vogeli, U. (1983). Chitinase in bean leaves: induction by ethylene, purification, properties, and possible function. Planta 157, 22-31.

Danulat, E. \& Kausch, H. (1984). Chitinase activity in the digestive tract of the cod. Journal of Fish Biology 24, 125-134.

Fuchs, R. L., McPherson, S. A. \& Drahos, D. J. (1986). Cloning of a Serratia marcescens gene encoding chitinase. Applied and Environmental Microbiology 51, 504-509.

GoODAY, G. W. (1977). Biosynthesis of the fungal wall - mechanisms and implications. Journal of General Microbiology 99, 1-11.

Hertelendy, F. \& Common, R. H. (1964). Separation of equol from oestrogens by thin-layer chromatography. Journal of Chromatography 13, 570.

Molano, J., Duran, A. \& CabiB, E. (1977). A rapid and sensitive assay for chitinase using tritiated chitin. Analytical Biochemistry 83, 648-656.

molano, J., Polacheck, I., Duran, A. \& Cabib, E. 
(1979). An endochitinase from wheat germ. Journal of Biological Chemistry 254, 4901-4907.

NitzCHE, W. (1983). Chitinase as a possible resistance factor for higher plants. Theoretical and Applied Genetics 65, 171-172.

Oranusi, N. A. \& Trinci, A. P. J. (1985). Growth of bacteria on chitin, fungal cell walls and fungal biomass, and the effect of extracellular enzymes produced by these cultures on the antifungal activity of amphotericin B. Microbios 43, 17-30.

OsAWA, T. (1966). Lysozyme substrates. Synthesis of $p$ nitrophenyl 2-acetamido-4-O-(2-acetamido-2-deoxy$\beta$-D-glucopyranosyl)-2-deoxy- $\beta$-D-glucopyranoside and its $\beta$-D- $(1 \rightarrow 6)$ isomer. Carbohydrate Research 1 , 435-443.

PegG, G. F. \& Young, D. H. (1982). Purification and characterization of chitinase enzymes from healthy and Verticillium albo-atrum-infected tomato plants, and from $V$. albo-atrum. Physiological Plant Pathology 21, 389-409.
Powning, R. F. \& IRZYkiewicz, H. (1965). Studies on the chitinase system in bean and other seeds. Comparative Biochemistry and Physiology 14, 127133.

ROBERTS, R. L. \& CABIB, E. (1982). Serratia marcescens chitinase: one-step purification and use for the determination of chitin. Analytical Biochemistry 127, 402-412.

Roberts, W. K. \& Selitrennikoff, C. P. (1986a). Isolation and partial characterization of two antifungal proteins from barley. Biochimica et biophysica acta 880, 161-170.

Roberts, W. K. \& Selitrennikoff, C. P. (1986b). Isolation and partial characterization of two antifungal proteins from barley. Journal of Cellular Biochemistry Supplement 10C, 26.

Schlumbaum, A., Mauch, F., Vogeli, V. \& Boller, T. (1986). Plant chitinases are potent inhibitors of fungal growth. Nature, London 324, 365-367. 